\title{
ARCHIVAL SOURCES TO THE HISTORY OF THE NETHERLANDS ANTILLES
}

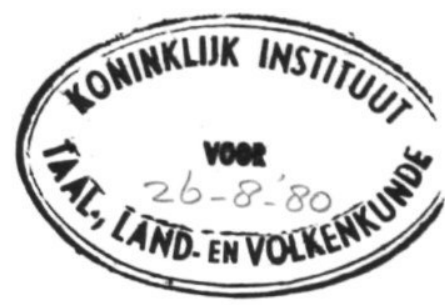

A CHALLENGE FOR ARCHIVISTS AND HISTORIANS

The Netherlands Antilles constitute no exception to a more general Caribbean pattern in that the majority of their earlier historians were of European origin. The last few decades, however, some discrepancy has emerged. Much later and to a much lesser degree than most other territories of the region the Netherlands Antilles started to go through the process of conscientization that gave birth to a historiography of, for, and (especially) by the proper citizens of the respective countries. More than anyone else I realize that the subject of this article might have had another flavour if it had been done by someone who is not only Curaçaoan by heart (like I feel) but also by birth. ${ }^{1}$

A second preliminary remark should be made. Done by a historian instead of an archivist, the following article clearly presents a consumer's point of view. The result is far from complete, and may certainly benefit from further research.

This article is meant to survey the main archival collections, both governmental and private; to mention the descriptions of and source publications from those collections; and to discuss historical research done and to be done. For practical purposes the subject has been divided into four parts. The caesuras usually applied to the history of the Netherlands Antilles - and derived mainly from the political history of Curaçao - have been faded out in order to let them coincide with the partitions used for archival collections. They relate to the Spanish period (from the end of the fifteenth to 
the middle of the seventeenth century), the old colonial period (the seventeenth and eighteenth century), the modern colonial period (the nineteenth and first half of the twentieth century), and the contemporary period. For obvious reasons more attention will be paid to the second and third, than to the first and fourth periods.

\section{THE SPANISH PERIOD}

In the Archivos de Indias at Sevilla, numerous documents relate to the era between Columbus' voyages at the end of the fifteenth century and the conquest of certain Caribbean islands by the Dutch in the first half of the seventeenth century. At the same place, 'travellers through the times' may bring to light many data on Curaçao, Bonaire and Aruba, on St. Eustatius, St. Martin and Saba (as well as other former Dutch West Indian possessions) in the years when they were not any longer part of the Spanish colonial empire. Of the documents relating to the period from 1621 to 1648 quite a few have been published by WRIGHT, and from the years 1639 and 1640 some have been printed by MADURO. But I would not be surprised if in Sevilla there was much more to be found than WRIGHT, MADURO, CARDOT and GosLINGA have incorporated in their books. ${ }^{2}$ However, given the lack of good entries and inventories, it is not to be expected that for the time being the Archivos de Indias will be combed out more thoroughly by a student of Dutch West Indian history. A description and analysis of Curaçao's position as a stepping stone between Hispañola and continental Latin America will have to wait for future historians.

\section{THE OLD COLONIAL PERIOD}

Most archival sources to the history of our islands under the first and second West India Companies and during the succeeding Napoleonic era are deposited in the Netherlands, especially in the General State Archives (GSA) at The Hague and in the Municipal Archives at Amsterdam. The GSA collections do not only include archives formed in the Netherlands, but also archival series formed in the West Indies by the local administrations. The latter have been transferred to Europe at the beginning of this century with the 
argument that they should be saved from complete destruction. ${ }^{3}$ Nevertheless, until very recently, those collections were not given much more care in the Netherlands than they had been given in the Caribbean. ${ }^{4}$ Anticipating the return of the 'transferred archives', a project was put in hand last year to make a major part of the transferred documents (and some of the WIC-archives) available at the Central Historical Archives (CHA) in Curaçao in the form of microjackets. ${ }^{5}$ With an eye to the conscientization mentioned in my introduction, it is regrettable that the selection of the documents to be microfilmed is not being done by one or more historians of Antillean origin, but by Dutch historians.

In addition to the large GSA collections, numerous smaller archival collections relevant to the history of the Netherlands Antilles are to be found in the Netherlands. It would carry me too far to mention them here, and this can be omitted all the more as they have been enumerated already by ROESSINGH. ${ }^{6}$

Outside the Netherlands important archival sources to our history in the years 1621-1816 lie in the United States, where part of the papers of Curaçao's administration found their way through Peter Stuyvesant and were rediscovered at Albany (N.Y.) after more than three centuries; in London at the Public Record Office, especially for the two periods of English government in Curaçao, and on the role of St. Eustatius in the American war of independence; in Paris at the Archives Nationales, in particular for the history of the island of St. Martin, peacefully shared by French and Dutch since 1648; in Rome, mainly with regard to missionary activities; in Copenhagen, on the settlements and commercial activities of the Curaçao Jews in the Virgin Islands; and, finally, in Sevilla, as has been mentioned before.

Finally, archival materials of interest for this period can be found within the Netherlands Antilles. From the old WIC-archives some solated documents or even series were overlooked when the zreater part of those archives were transferred to the Netherlands. Among the private archival collections the major ones are those of he plantations (mainly titles, deeds, and inventories), and of the hurches and the synagogue (diaries, and registers of birth, aarriage and death). But an important part of the ecclesiastical rchives has been lost in the fire of the catholic bishop's palace in 
1969, and from other private collections much has disappeared (and still does disappear) through neglect, alienation and collectors' crazes.

Not all archival collections mentioned have been described from the viewpoint of their relevance to the history of the Netherlands Antilles. In 1955 already MEILINK-RoELOFSZ published her 'Survey of archives in the Netherlands pertaining to the history of the Netherlands Antilles', a detailed summary covering the material in the General State Archives; ${ }^{7}$ the article was revised for the first Caribbean Archives Conference in $1965 .^{8}$ More recently vAN OPSTALL made a somewhat comparable survey for students of slavery and plantations. ${ }^{9}$ More detailed are the anonymous manuscript inventories of the two Dutch West India Company archives. Later, BIJLSMA made inventories of the archives transferred from the Dutch West Indian islands immediately upon their arrival in The Hague. ${ }^{10}$ The publications mentioned together constitute a fairly good introduction, but for more detailed studies additional indices would be useful. The making of such indices is being considered in connection with the micro-jacket-project. For the other collections in the Netherlands I referred already to ROESSINGH's excellent Guide to the sources in the Netherlands for the bistory of Latin America, which also covers the Netherlands Antilles.

Of the old archives in the United States SCHILTKAMP has published a general enumeration that does not pretend to be exhaustive but is quite workable. ${ }^{11}$ No selective surveys exist on sources for Antillean history in the archives of London, Paris, Copenhagen, Rome or Sevilla. In some archives - like Sevilla's - such a survey can certainly only be made at the cost of disproportionate effort; but in other places - and here I would like to think of London in particular - a rather modest effort may produce the heuristic framework that is indispensable for the promotion of Antillean historiography. I offer no opinion on the question how this task has to be divided among historians and archivists.

At home, we find similar work to be done. Since MeILINK-RoELOFSZ' provisional and incomplete description in $1966,{ }^{12}$ no thorough surveys (let alone inventories) have been made of the non-transferred government archives and of the older private collections within the Netherlands Antilles. The list of a few plan- 
tation archives, published by FeLHOEN KRAAL as early as in $1956,{ }^{13}$ waits for the additions that are most probably going to be made by RENKEMA and VISMAN. For lack of inventories, we do not know what has been lost from the bishop's archives in 1969.

The horror-stories that are circulating with regard to the government archives from the old and new colonial period are more than false rumours if one is to believe an expert's survey made only three years ago. ${ }^{14}$ Apparently the Netherlands Antilles are caught in a paradoxical situation: from one side they demand that the voluminous archives, transferred half a century ago because of neglect, be returned, but from the other side they do not demonstrate their ability to take care even of the small quantities that were left behind. The well-established departments for restoration and microfilming of the Antillean archival service nowadays devote their capacities almost completely to nineteenth and twentieth century documents; one may ask whether under the circumstances their employers apply the right priorities. What has been left of archival materials from the seventeenth and eighteenth century should, as far as such has not yet been done, immediately be deposited with the Central Historical Archives; here those archives should be inventoried, restored and microfilmed with absolute priority and on the shortest term possible.

After the preceding survey it is not surprising that almost all source publications on the discussed period have been distilled from the collections in the General State Archives in The Hague. HAMELBERG's series of documents were far from complete or balanced, but had the virtue of being the first. ${ }^{15}$ Later came L'HONORÉ NABER's edition of the 13-volume history of the WIC during its early years by contemporary DE LAET. ${ }^{16}$ More recently the official documents relating to the slave rebellion of 1795 have been published by the CHA in Curaçao (be it from GSA-sources). ${ }^{17}$ Last year saw the publication of the impressive Plakaatboek, containing all colonial laws of the seventeenth and eighteenth century that could be found. ${ }^{18}$

In the meantime rather few historians have devoted their time to monographs on the history of the Netherlands Antilles in the old colonial period. I already mentioned the names of GosLINGA and 
SCHILTKAMP, who did notable research, and should add now the valuable studies by VAN GROL, the EMMANUELS, KNAPPERT and ATTEMA, and the (less accurate) works of HAMELBERG and HARTOG. ${ }^{9}$ With those publications the seventeenth and eighteenth centuries have certainly not been dealt with exhaustively. One might even say that the main sources to the history of the period, the archives of the West India Companies, have still hardly been explored.

Although some of the islands of the Netherlands Antilles were of particular importance as international commercial centres, their economic history has never been studied in detail. Very little is known, e.g., about their roles in the slave trade, ${ }^{20}$ and about their other economic relations, especially in the staple trade, with their Caribbean and continental neighbours; the internal economy of the islands has also still to be described in more than generalizing or oblique ways. Such studies on internal and international economic relations would contribute substantially to a more general economic history of the Dutch West Indies under Companies' rule. For the latter, financial (including monetary) history will also be an undispensable component. The origin, volume, destination and other qualifications of the capital-flows involved in trade, public administration and defense, are attractive subjects for research and may fit into economic as well as social and political history.

As long as no new inventories and detailed registers have been made of the Companies' archives, it remains an open question whether they contain sufficient data for research in social history that might lead us further than the general description of early Curaçao society by HOETINK. ${ }^{21}$ In this connection it should be stressed that even the largest and most cosmopolitan of the Dutch West Indian islands had a population of not yet 15.000 at the end of the eighteenth century: a microcosmos.

In the field of political, administrative and legal history, subjects are easier to be defined. During the next few years it may be expected that the Law Department of the University of the Netherlands Antilles will initiate several studies on the operation of Old Dutch and Roman law under the tropical sun. 


\section{THE NEW COLONIAL PERIOD}

The principal archival sources to the history of the nineteenth and early twentieth century are again to be found in the Netherlands and in Curaçao. Minor quantities, but with important data, may be expected in London, at the Public Record Office, in the company archives of Shell and in the private papers of the Godden family (who since 1871 exploited Curaçao's phosphates); in Washington, especially on the nineteenth century expansion across the Caribbean of U.S. economic interests, and elsewhere in the United States, such as the headquarters of the various oil companies; in Caracas, in particular with regard to the intricate Dutch-Venezuelan political relations, but also on economic relations between Curaçao and the ports of the mainland; in Bogotá, in Rome, in Paris, in Copenhagen, and probably even in Madrid. Not much can be said of any of them, as - as far as I am aware - no researcher has ever visited those places with the specific purpose of collecting data on new Antillean history.

In the Netherlands, the main repository is again the General State Archives, where two main collections should be discerned. In the first place there are the Dutch govermental archives from the period 1813-1939. The most conspicuous of these for our purpose are the collections formed within the Ministry for the Colonies, but those of the General State Secretariat and of the Ministry of Foreign Affairs should not be ignored. In the second place there are again archives transferred from the West Indies. They must be distinguished in two parts: the documents for the years between 1816 and 1828, which have been transferred first, together with the old WIC-archives; and the documents for the period 1828-1845 (together with a few records from later years) that have been transferred a decade after the WIC-archives.

Relatively few family-archives are accessible in public repositories; I only mention the papers of VAN DEN BOSCH, VAN GROL, and Rollin COUQuerQue in the General State Archives for their relevance to our subject. Among the company-archives in public repositories (according to DE BOOY \& LOOIJENGA there are about one thousand of them $)^{22}$ not even a dozen are of interest for the history of the Netherlands Antilles. Much more worthwhile are 
the company-archives in the private, mostly corporate, hands of the Royal Dutch/Shell Group at The Hague, of OGEM at Rotterdam, and of the Royal Netherlands Steamship Company, the Curaçao Trading Company, the Curaçao Mining Company, Royal Dutch Airlines KLM, and the ABN-Bank at Amsterdam - to mention only the bigger Dutch companies operating in the Netherlands Antilles.

On the islands of the Netherlands Antilles there are in the first place some governmental records on the years prior to 1845 . They have been overlooked at the time of the transfers of 1916, 1920 and 1930, and have since fallen into further neglect. For the years from 1845 to 1939 most government documents rest at the Central Historical Archives in Curaçao. In 1939 a decimal classification to subject was introduced for general use in the government registry. During the years that followed an enormous number of documents was picked rather arbitrarily from the pre-1939 series and regrouped into well over 2000 subject files, most of which are now to be found in the Central Historical Archives. The subject files are far from complete and have no detailed inventories, whereas, for the ransacked series, no record has been kept that tells what documents have or have not been taken out. So the completeness of the old series and new files combined can never be checked. ${ }^{23}$ Moreover, the divisions and subject classifications used lead to many misunderstandings. Nevertheless it should be admitted in fairness that the artificial system facilitates a first exploration of many a historical subject, and thus has its advantages at the rather embryonic stage of development of historical research in the Netherlands Antilles.

Among the important collections of nineteenth and early twentieth century government documents outside the $\mathrm{CHA}$, the most voluminous probably is the archive of the Court of Justice in Curaçao. Close seconds are the archives of the Recorder of Mortgages (since 1869), also in Curaçao, and the older parts of the records of the island government of Aruba, in Oranjestad. A similar collection of records in the government offices of St. Martin has been destroyed by fire in 1974. In Curaçao the central office of the island government has no such records, because until 1951 the administration of this island and of the colony as a whole coincided almost 
completely; older documents may here be found with the specific departments and services. The Office of the Domain has deeds etc. dating back to the eighteenth and sometimes even seventeenth century. The piles of archival documents at the Public Works Department (mostly late nineteenth and early twentieth century) still lie in about the same state of decay that shocked MEILINK-ROELOFSZ in 1966.12 The older registers of births etc. at the Registrar's Office are in good order and well kept.

With regard to the nineteenth and early twentieth century the Netherlands Antilles have many more private archival collections than is usually assumed. In the first place there are the sequels to the ecclesiastical and plantation records mentioned before; here the corresponding remarks on loss by fire, neglect, and alienation apply. Next, reference should be made to the archival sources of Curaçao's St. Elisabeth Hospital (since 1855), of the masonic lodges, and of burial and other societies. Many data for our history rest in company archives, of which only the most prominent can be mentioned here. The extensive records of Shell differ from those of the company's headquarters in The Hague in that Curaçao has more on local details and Holland has more on overall policy. The other Dutch companies in the Netherlands Antilles, such as the Royal Netherlands Steamship Company, OGEM, KLM and the mining company, keep almost no older archives, because these have been destroyed or sent to the metropolitan headoffices. Among our own Curaçao enterprises, the oldest and one of the biggest of the still existing commercial firms is S.E.L. Maduro \& Sons (since 1837); they have a great quantity of documents, but only a small part of these are kept in good order. Of the financial institutions, the Centrale Bank van de Nederlandse Antillen has remarkably complete archives, going back to 1828 . The records of the Spaar- en Beleenbank van Curaçao (savings and pawn bank, since 1850) and of the Curaçaosche Hypotheekbank (mortgage bank, since 1875) have been handed over to the Central Historical Archives a few years ago. Lago Oil and Transport Company, Exxon's subsidiary in Aruba, has probably the most important company records outside Curaçao; but no outsider has ever been allowed to cast even a distant glance at their files, and until now nobody of Lago itself was able or willing to tell in what condition 
these files are and what they may contain.

The list of private archival caches can not be complete. Almost weekly smaller or (rarely) bigger collections are brought to light, sometimes by lucky accident, sometimes by the increasing awareness of their owners or keepers. However, until today the official archival service never initiated a co-ordinated and well-directed treasure-hunt. Yet a complete survey of all private archival sources to the history of the Netherlands Antilles would greatly enhance the promotion of our historiography. Archivists, historians, and the generally interested public (as e.g. united in the St. Eustatius Historical Foundation and the Curaçao Historical Society) should together make an effort to form such a thesaurus.

A complete catalogue would not only facilitate research but might also be an aid in the struggle against the often thoughtless destruction of useful archival sources. To halt this destruction, the CHA might expedite the introduction of the new archival legislation which has lingered on since 1973, and might also develop an active policy of conservation. This policy should then aim to work along two lines at th same time. Firstly, a kind of field service operating from the $\mathrm{CHA}$ can give expert advice to the owners and keepers of old records, both governmental and private. And, secondly, the CHA can stimulate the transfer of dispersed collections (again: governmental as well as private) to the CHA, whether in property or in custody, and with or without additional agreements on the accessibility of the documents concerned. The lack of shelfroom and storage space - subject of justified complaints by the CHA since many years - may not any longer be used as an excuse to postpone such a policy of active acquisition. The conditions of many archives have become too delicate for that.

What inventories have been made of the archival sources to new Antillean history? At the General State Archives, most collections stemming from Dutch public administrations have been inventoried, those of the Ministry for the Colonies from 1814 to 1900 by FASEL. ${ }^{24}$ The records transferred from the West Indies have partly (for the years up to 1828) been included in BIJLSMA's inventories, ${ }^{10}$ partly (for the period after 1828) summed up in type- 
written inventories by an anonymous archivist. Inventories are also available of a few family-archives at the GSA, notably the papers of VAN DEN BOSCH. ${ }^{25}$ Among the company archives, the good inventories of the records at Shell's headquarters are commendable. ${ }^{26} \mathrm{I}$ am not informed on professionally done inventories of other company, family of ecclesiastical collections in the Netherlands relevant to Antillean history.

Within the Netherlands Antilles the remnants of the transferred nineteenth century archives ask for the same note as the left-overs of the older transferred archives: since the indicative list compiled by MEILINK-ROELOFSZ in 1966 no further surveys or inventories have been made. ${ }^{12}$ The records of the period 1845-1939 have been removed various times over the last forty years, they have been regrouped time and again, and carry at least three serial numbers on each unit. The provisional entry, made by BOSKALJON, ${ }^{27}$ had since long to be replaced by a new, equally provisional, listing of all records at the Court of Justice, recently made by J.Th. DE SMIDT (a job has been done in the last few years. In addition, the accessibility of the artificial subject files has been improved by some sort of alphabetical topical index. ${ }^{28}$ In the meantime the CHA has sent several members of its staff abroad for archival training on elementary and secondary level. The return of one assistant with special training in the making of inventories has already given a fresh impetus to this indispensable work at the CHA.

Leaving the CHA, I mention the preliminary inventory of the records at the Court of Justice, recently made by J. TH. DE SMIDT (a visting professor of law history) and some students of the University of the Netherlands Antilles. ${ }^{29}$ In Aruba one man has made a start with the older archives of the island government, but for lack of assistance he has no prospect of finishing this work within the near future. None of the older collections deposited with the various departments of the Curaçao island government have inventories; neither do any plans exist for the making of such lists. The excuse that those records belong to current administrations can not be taken seriously for the documents dating from before 1939 .

Shell Curaçao has a reasonable entry to its company records, be it not of the same quality as the inventories at The Hague. Beside this one, I know only of provisional lists of the old records of the Bank 
van de Nederlandse Antillen, the Spaar- en Beleenbank van Curaçao and the Curaçaosche Hypotheekbank, made by myself and a number of students over the last decade. ${ }^{30} \mathrm{~A}$ few years ago the management of S.E.L. Maduro \& Sons showed some willingness to have their archives put in order and listed, but no followup has been given to this idea after a change of the guard. In this connection it may be useful to say that the making of inventories of company archives must not be viewed as inevitably leading to the immediate opening of these records to the public; a company can also bring some order in its old documents with a view to a more remote future.

Publications of sources to the history of the Netherlands Antilles in the nineteenth and early twentieth century are relatively scarce. DE HULLU and DE GAAY FORTMAN published some documents from the beginning of the last century. ${ }^{31}$ BORDEWIJK printed the basic documents on constitutional developments in the nineteenth century. ${ }^{32}$ VAN ZANEN took care of the works of physician David Ricardo Caprilles. ${ }^{33}$ Remotely allied to Antillean history is VAN NOUHUYs' publication of documents relating to the first all-steam crossing of the Atlantic by a ship called 'Curaçao' and heading to this island. ${ }^{34}$ Together with the inevitable reprints of old travelstories, ${ }^{35}$ the list is then complete. Which is regrettable, for in Willemstad as well as in The Hague and elsewhere there are quite a few documents that are not easily accessible but are basic to any study of Antillean history and should for this reason be widely available. I think of the annual governor's reports with their statistical annexes, especially those of the early nineteenth century but also the later ones; the studies and documents that bear on the emancipation of the slaves (think e.g. of the reports of the Royal Commission of 1853); selections from laws and by-laws; documents on Curaçao-Venezuelan relations; and many more that can be added to this arbitrary bid. An enormous field lies fallow for archivists and historians.

As a consequence of the better conditions of the archives, the availability of non-manuscript sources such as newspapers, books and pamphlets, and of nonwritten visual and oral sources, it is no wonder that more has been published on the nineteenth and twenti- 
eth century than on the previous ages. However, there are still various gaps to be filled, and not only for shorter periods or very specialised areas but often also for wider themes and for the whole time-span. So the political history for this century and a half has hardly been studied. BORDEWIJK paid attention to legal aspects only, and KASTEEL and VAN HELSDINGEN concentrated on the years after 1940.36 The numerous articles by DE GAAY FORTMAN can not fill the gap. ${ }^{37}$ Among the topics that still deserve to be studied I mention only a few: Dutch colonial policy and the reaction to it in the islands; the relations amongst the islands of the Netherlands Antilles (a very relevant subject, as the islands nowadays threaten to split on the way to independence); the history of political pressure groups and the representation of the people in general (for the latter a research project has been initiated recently in Curaçao).

In the field of international relations, the political relations between Curaçao and Venezuela are the only ones that have been subjected to certain investigations, although the works of CORPORAAL and GOSLINGA are both limited to the nineteenth century and leave the more recent developments to others. ${ }^{38}$ Much might also be said on the relations with Colombia, Suriname, Cuba, the Dominican Republic, and Jamaica. They can not be studied from a purely political point of view and will have to be seen in the context of international economic relations.

On the economic history of the nineteenth and twentieth century a general survey has been published by VAN SOEST. ${ }^{39}$ Certain themes have been further elaborated by DE JONG, HARTOG, and VAN SOEST, or are right now being worked by RENKEMA. ${ }^{40} \mathrm{But}$ many aspects deserve further investigations: transport and communications, the government's role in the promotion of economic development, Aruba in the era of the oil refinery, etc. In the preparation of several research projects, the complete absense of historical-demographic studies will be noticed as a vacuum that has also to be filled.

The social history has attracted some attention through the works of GoslingA, HoETINK, EMmer and Römer. ${ }^{41}$ Among the missing links here is the history of the labour movement in general and of the labour unions in particular. In the sociocultural field, finally, the numerous smaller publications on church 
history ${ }^{42}$ present many facts but less insights; they should be deepened and integrated in a book-length study. Almost nothing has been done on the history of education and educational institutions. ${ }^{43}$ The histories of Antillean music and literature have not yet been printed, with the exception of fragments by BOSKALJON and DEBROT. ${ }^{44}$ Architecture has certainly not been exhausted with the precious book of OzINGA. ${ }^{45}$ In health care also ample opportunities are left after the reader of STATIUS VAN EPS \& LUCKMANMADURO; 46 the hospital is at present the subject of a historical investigation.

\section{THE CONTEMPORARY PERIOD}

The main documental data for the history of the Netherlands Antilles after 1940 still form part of current administrations and can not be considered as archival sources in the full sense. The few series that have been closed are affected by legal standards of accessibility. This goes e.g. for the complete archives of the Ministry for the Colonies during the second world war, and for its successors after 1945. ${ }^{47}$ They come under the Dutch law that only documents older than 50 years are open to the public. There is, however, a tendency to reduce this term to 30 years, and in many places the keepers of archives anticipate the formalization of that development.

Less rigorous rules on accessibility in the United States, where important sources for the history of the Netherlands Antilles in the second world war are to be found in Washington. I do not know what rules are applied to this respect in London, Paris and Caracas, and no archival authority in the Netherlands Antilles could inform me on this.

Under the administrative regulations of 1939 all government records remained with the General Secretariat of the Governor in Curaçao. ${ }^{48}$ This body was split into several services in 1968/ 1969.49 The CHA then received móst archival material that was over 30 years old, i.e. dating back to before the year 1939. The Central Office of Registry and Archives got the rest: files on current affairs as well as files that were no longer in demand but had been formed after 1939 (the latter may also contain documents 
taken from pre-1939 records). The head of the Central Registry has now made a plan to hand over the closed files (the so-called static parts) of his collection to the CHA. These archives are well kept and indexed professionally. Also this Office has made a start with an advisory service on behalf of other administrations, in particular of the Antillean government. For future archivists and historians much will depend on the results of this field service.

When the separate islands of the Netherlands Antilles received a certain degree of self-government, in 1951, the island government of Curaçao established a new administration of its own and also took over certain departments and services of the former colonial administration. The island governments of Aruba, Bonaire and St. Martin converted the existing dependencies of the central administrations into their own administrations as well. The islands work with a decimal code that is almost identical to the code used by the Central Registry - which makes work easier for historians-to-be. The day to day management of the various collections is not of the same standard quality in all islands. Moreover the main registries in Curaçao and Aruba do not control the archives of the different departments and services, although experience shows that such a control is most desirable.

In principle the records of the central and islands' governments are not open to the public, although in practice they may sometimes be consulted with the express consent of the responsible minister or island government. This implies that even documents from pre-war years which happen to rest in those archives are not directly and unconditionally accessible. This situation will change with the introduction of a new archival legislation. It is expected that under the new law documents of over 30 years of age will be open to the public, but only in so far as they are deposited with the $\mathrm{CHA}$. At the same time the law will stipulate the obligation that all archival materials of over 30 years old in any of the central or isands' administrations be transferred to the CHA. (An extra argunent for the soonest introduction of this law lies in the fact that the IHA's capacity to act as recipient has then to be expanded, and nore shelfroom may then also come available for the acquisition of on-governmental archives at the same time). 
No studies on the contemporary history of the Netherlands Antilles have been based predominantly on the use of archival sources. VAN HELSDINGEN comes close to being an exception; he saw and made use of the archives of the Ministry for the Colonies. ${ }^{36}$ KASTEEL saw some government documents in Curaçao, and more recently VAN SOEST had access to the files of the Central Registry and of a few departments of the island government of Curaçao. ${ }^{39}$ The other studies of contemporary developments rely heavily on published sources or on verbal information, and are sociological or anthropological rather than historical. ${ }^{50}$ Obviously, ample freedom to consult the relevant records is an absolute condition for any serious historical research on the Netherlands Antilles during the second world war, on constitutional developments up to 1954 , on labour relations, on economic developments, etc.

\section{Tentative CONCLUSIONS}

(a) The study of history by the proper citizens of the Netherlands Antilles should be stimulated, as a contribution to the processes of cultural conscientization and political decolonization.

(b) A general survey should be made of all archival collections, both within and outside this country, relevant to the history of the Netherlands Antilles.

(c) A policy of active acquisition by the Central Historical Archives, in Curaçao, is an urgent necessity with regard to the remaining archival sources (both governmental and private) from the seventeenth and eighteenth century, and is highly desirable for archival collections from the nineteenth and early twentieth century. (d) Pending the establishment of a new public records office-building in Curaçao, the shelfroom and storage space of the $\mathrm{CHA}$ should be extended considerably on short notice.

(e) A dialogue should be initiated between all persons actively involved in the study of Antillean history. Such a discussion should aim at the identification of the blank and weak spots in our knowledge, and should also lead to the indication of-the periods and themes that are to be studied with some priority. 


\section{NOTES}

1. An earlier version of this article was submitted as a discussion-paper to the Eleventh Conference of Caribbean Historians, Curaçao, 5-10 April 1979. The author wishes to thank Mr. W.E. FORTIN for his friendly cooperation in the preparation of that paper.

2. Wright, I.A. - Nederlandse zeevaarders op de eilanden in de Carä̈bische Zee en aan de kust van Columbia en Venezuela. Deel I en II, 1621-1641, 1635-1648. Utrecht, 1934.

Maduro, A.J. - Documenten uit de jaren 1639 en 1640, welke zich in de 'Archivo General de Indias' bevinden... Documentos de los años 1639 y 1640 que se encuentran en el Archivo de Indias en Sevilla... Willemstad, 1961

Cardot, C.F. - Curazao Hispánico: Antagonismo Flamenco - Español. Caracas, 1973.

GosLingA, C.Ch. - The Dutch in the Caribbean and on the Wild Cost, 1580-1680. Assen, 1971.

3. Royal Decrees of 22 December 1915, 7 July 1919, and 12 May 1930.

4. See a.o. M. VAN OPSTALL - De koloniale archieven dienen beschermd te worden. Trefpunt, october 1972, p. 239-241.

5. Paula, A.F. - A microfiche project to complete the Archives of the Netherlands Antilles. Working paper for the Second Caribbean Archives Conference, (1975).

6. ROESSINGH, M.P.H. - Guide to the sources in the Netherlands for the bistory of Latin America. The Hague, 1968.

7. MeIlink-RoelofSZ, M.A.P. - A survey of archives in the Netherlands pertaining to the history of the Netherlands Antilles. West-Indische Gids 35, 1955, p. 1-38.

8. MEILINK-ROELOFSZ, M.A.P. - A survey of the archives pertaining to the bistory of the Netherlands Antilles in the General State Archives in the Hague. Paper for the First Caribbean Archives Conference, 1965.

9. OpStal, M.E. van - Archival sources in the Netherlands. Comparative perspectives on slavery in new world plantation societies (edited by Vera Rubin and Arthur Tuden), New York, 1977, p. 501-509.

10. BIJlsma, R. - Het oud Archief van Curaçao en onderhoorige eilanden Bonaire en Aruba. Verslagen omtrent 's Rijks oude archieven 42 (1). Annex 12. The Hague, 1920 (p. 617-687).

Bijlsma, R. - Het oud Archief van Curaçao en onderhoorige eilanden Bonaire en Aruba. Supplement. Verslagen omtrent 's Rijks oude archiven 47 (1). Annex 8. 1924 (p. 133-144).

BIJLSMA, R. - De oude archieven van St. Eustatius, Sint-Martin en Saba. Verslagen omtrent 's Rijks oude archieven 47 (1). Annex 7. 1924 (p. 99-132).

11. SCHILTKAMP, J.A. - De geschiedenis van bet notariaat in bet octrooigebied van de West-Indische Compagnie. The Hague, 1964. 
12. MeIlinK-Roelofsz, M.A.P. - Een archiefreis in West-Indië. Report, 16 May 1966. Also published in Nieuwe West-Indische Gids 46 (3), Dec. 1968, p. 261-287, and 47 (1), Sep. 1969 , p. 67-90.

13. FeLHOEN KRAAL, J. - Libraries and archives for research in West Indian history. With an appendix on a collection of Curaçao plantation archives. West-Indische Gids 37(2/4), 1957 , p. $71-92$

14. MEERENDONK, H.J. vAN - Advies inzake de archiefdiensten van de Nederlandse Antillen. (unpublished report) 2 April 1976.

15. HAMELBERG, J.H.J. (ed.) - Documenten behoorende bij 'De Nederlanders op de West Indische eilanden'. - I. Curaçao, Bonaire, Aruba. Amsterdam, 1901. - II. St. Eustatius, Saba, St. Martin. Amsterdam, 1903.

16. HONORÉ NABER, S.P.1' (ed.) - J. de Laet: Iaerlyck verhael van de Verrichtinghen der Geoctroyeerde West-Indische Compagnie in dertien boeken, 1624-1636. 4 vols., The Hague, 1931-1937.

17. 1795 de slavenopstand op Curą̧o: een bronnenuitgave van de overbeidsdocumenten. Curaçao, 1974.

18. SChiltKAMP, J.A., and J.Th. DE SMIDT (eds.) - West Indisch Plakaatboek. Publikaties en andere wetten alsmede de oudste resoluties betrekking bebbende op Curaçao Aruba Bonaire. I, 1638-1782. Amsterdam, 1978.

19. See note 2 for GosLinga, and note 11 for SCHILTKAMP.

GROL, G.J. VAN - De grondpolitiek in het West-Indische domein der Generaliteit. - I. Algemeen bistorische inleiding. The Hague, $1934-$ II. De rechtstoestand van het grondbezit. The Hague, 1942.

EmmanUel, I.S. and S.A. EmmanUel - History of the Jews of the Netherlands Antilles. 2 vols., Cincinnati, 1970.

KNAPPERT, L. - Geschiedenis van de Nederlandse Bovenwindse eilanden in de $18 \mathrm{e}$ eeuw. West-Indische Gids 11, 1929/1930, p. 353-386, 421-436, 513-541, 559-574 12 , 1930/1931, p. 31-42, 73-84, 161-178, 279-290, 325-338, 423-440, 471-484, $573-590 ; 13,1931 / 1932$, p. $177-202$, 249-268, 545-568; 14, 1932, p. $25-41$.

ATtEMA, Y. - St. Eustatius, a short history of the island and its monuments. Zutphen, 1976.

Hamelberg, J.H.J. - De Nederlanders op de West-Indische eilanden. 2 vols., Amsterdam, 1901, 1903.

HARTOG, J. - Aruba, zoals het was, zoals het werd. Aruba, 1962.

Hartog, J. - Curą̧ao, van kolonie tot autonomie. Aruba, 1961.

HARTOG, J. - De Bovenwindse eilanden St. Maarten, Saba, St. Eustatius, eens gouden rots, nu zilveren dollars. Aruba, 1965.

HARTOG, J. - Bonaire, van indianen tot toeristen. Aruba, 1957.

20. Some of the islands that today form part of the Netherlands Antilles played an important role in the international slave trade. Studies on this subject by Dutch authors (e.g. UNGER, POSTMA, EMMER, VAN WINTER) have all been done from an African and/or Dutch point of view, touching only tangentially on the islands; until now, no com- 
parable study from a (Dutch) Antillean point of departure exists.

21. HoEtinK, H. - Het patroon van de oude Curą̧aosche samenleving. Leiden, 1958.

22. BOOY, E.P. DE, and A.J. LOOJENGA - Overzicht van archieven van particuliere ondernemingen berustend in openbare archiefbewaarplaatsen. N.pl., 1975.

23. It is not even known how many of such artificial files have been made; one can still find them in the attics of government offices.

24. FASEL, W.A. - Inventaris van het archief van het Ministerie van Koloniën, 1814-1849. Idem, 1850-1900. The Hague, 1954. See also: PIRENNE, L.P.L. (ed.) - De Rijksarchieven in Nederland. 2 vols., The Hague, 1973; and

WONDAAL, H.G. and R. BRAAD - Overzicht van de archieven geplaatst in het hulpdepot van het Algemeen Rijksarchief in Schaarsbergen. The Hague, 1975.

25. JONGH, G.J.W. DE - Beschrijving van een verzameling stukken afkomstig van Johannes van den Bosch en enige van zijn nakomelingen. N.pl., 1968,

26. Voerman, V.P. - Selectie en inventarisatie van het archief van Shell Internationale Petroleum Maatschappij B.V. Nederlands Archievenblad 79, 1975, special edition.

27. Inhoud inventaris Boskaljon. Typescript, n.pl., n.y., 104 pp.

28. Klapper op de objectendossiers van het Centraal Historisch Archief. N.pl., 1970.

29. Archief Hof van Justitie. Inventaris. N.pl., 1978.

30. Curaçaosche Bank. Voorlopige inventaris Oud-Archief. Typescript, 16 pp. (made in 1973). Inhoud (van het archief van de N.V. Curaçaosche Hypotheekbank). Typescript, $10 \mathrm{pp}$. (made in 1973).

(Lijst van documenten in het archief van de Spaar-en Beleenbank van Curaçao). Manuscript, 35 pp. (made in 1976).

31. Hullu, J. DE - Bonaire in 1816. West-Indische Gids 4, 1923, p. 505-511.

HULLU, J. DE - Aruba in 1816. West-Indische Gids 5, 1923, p. 371-382.

HULLU, J. DE - Curaçao in 1817. Bijdragen van bet Koninklijk Instituut voor Taal-, Land-en Volkenkunde 67, 1913, p. 563-609.

GAAY-FORTMAN, B. DE - Brieven van den Commissaris-Generaal van de (Nederlandsche) West-Indische bezittingen J. van den Bosch aan den Minister voor de Marine en de Koloniën (1827-1829). Bijdragen en Mededeelingen van bet Historisch Genootschap 51, 1930, p. 189-335.

32. BORDEWIJK, H.W.C. - Ontstaan en ontwikkeling van het staatsrecht van Curaçao. The Hague, 1911.

BORDEWIJK, H.W.C. - Handelingen over de reglementen op het beleid der Regering in de koloniën Suriname en Curaçao. The Hague, 1914. 
33. ZANEN, G.E. vAN - David Ricardo Caprilles: student, geneesheer, schrijver. Assen, 1969.

34. NouhuYs, J.W. van - De Eerste Nederlandsche Transatlantische Stoomvaart in 1827 van Zr.Ms. Stoompakket 'Curą̧ao'. The Hague, 1927.

35. BosCH, G.B. - Reizen in West-Indië en door een gedeelte van Zuid-en Noord-Amerika. 3 vols., Utrecht, 1829, 1836, 1843.

BRUSSE, A.T. - Curaçao en zijne bewoners. Curaçao, 1882.

HERING, J.H. - Beschrijving van het eiland Curaçao en de daaronder behorende eilanden Bon-Aire, Oroba en Klein Curaçao. Amsterdam, 1779.

SIMONS, G.J. - Beschrijving van het eiland Curaçou, uit verschillende bronnen bijeenverzameld. Oosterwolde, 1868.

36. For BORDEWIJK, see note 32.

KASTEEL, A.C.T. - De staatkundige ontwikkeling der Nederlandse Antillen. The Hague, 1956.

HeLSDINGEN, W.H. vaN - De Eilandenregeling Nederlandse Antillen. The Hague, 1963.

HeLSDINGEN, W.H. vaN - De Staatsregeling van de Nederlandse Antillen van 1955. The Hague, 1956.

Helsdingen, W.H. van en Th. VAN DeR PeYL - Het Statuut van bet Koninkrijk der Nederlanden. The Hague, 1957.

37. DE GAAY FORTMAN has been a prolific writer; most of his publications are mentioned in NAGELKERKE, G.A. - Nederlandse Antillen. Literatuuroverzicht vanaf de 17 e eeuw tot 1970. Leiden, 1973, pags. 32-38.

38. CORPORAAL, K.H. - De internationaalrechtelijke betrekkingen tusschen Nederland en Venezuela, 1816-1920. Leiden, 1920.

GosuINGA, C.Ch. - Curaçao and Guzman Blanco: a case study of small power politics in the Caribbean. The Hague, 1975.

39. SOEST, J. VAN - Trustee of the Netherlands Antilles: a bistory of money, banking and the economy... Curaçao, 1978.

40. JONG, TH. DE - De krimpende horizon van de Hollandse kooplieden. Hollands welvaren in bet Caribisch zeegebied, 1780-1830. Assen, 1966.

HARTOG, J. - Het verbaal der Maduro's... 1837-1962, Aruba, 1962.

Hartog, J. - U.S. Consul in the 19th century Curaçao. The life and works of Leonard Burlington Smith. Aruba, 1971.

SOEST, J. VAN - Olie als Water. De Curaçaose economie in de twintigste eeuw. Curaçao, 1976.

41. GoslingA, C.Ch. - Emancipatie en emancipator. Assen, 1956.

HoEtıNK, H. - Het patroon van de oude Curaçaose samenleving. Assen, 1958.

EMMER, P. - Engeland, Nederland en Afrika en de afschaffing van de slavenhandel in de negentiende eeuw. Leiden, 1974.

RÖMER, R. - Un pueblo na kaminda. Een sociologisch-historische studie van de Cura̧̧aose samenleving. Curaçao, 1977. 
42. Notably by Brada (1951, 1961), Dalhaus (1924), Euwens (1932), Hartog (1970), LATOUR $(1949,1951)$, and NoOIJEN $(1945-55,1974)$.

43. PRINS, F.W. - Latent taaltalent. Zeist, 1974.

44. Boskaljon, R. - Honderd jaar muziekleven op Curaçao. Assen, 1958.

Debrot, N. - Verworvenheden en leemten van de Antilliaanse literatuur. Cultureel Mozaïek van de Nederlandse Antillen (onder redactie van R.A. Römer), Zutphen, 1977 , p. $96-138$.

45. OzIngA, M.D. - De monumenten van Curaçao in woord en beeld. The Hague, 1959.

46. StatiUS VAN EPS, L.W., and E. LUCKMAN-MADURO (eds.) - Van scheepschirurgijn tot specialist. 333 jaar Nederlands-Antilliaanse geneeskunde. Assen, 1973.

47. LAAR, E. VAN - A survey of the archives in the Netherlands pertaining to the bistory of the Caribbean area. The Hague, 1975.

48. Government Orders of 21 December 1938 nr. 2716, and of 12 October $1945 \mathrm{nr}$. $8027^{b}$.

49. Government Decisions of 8 December 1967 nr. 20, and of 26 August 1969 nr. 34 (Official Publications 1967 nr. 210 and 1969 nr. 128).

50. Works by Crane (1971), MARKS (1973), Abraham-VAN DER MARK (1973), GreEN (1974), ANDERSON \& DYNES (1975) and VERTON (1977).

Dr. JAAP VAN SOEST

Tinweg 20, Curaçao. 